\title{
The Need to Value and Protect Coastal and Insular Karst of the Republic of Croatia
}

\author{
Lidija Runko Luttenberger* \\ Department of Polytechnics, University of Rijeka, Croatia
}

Submission: December 14, 2019; Published: January 23, 2020

Corresponding author: Lidija Runko Luttenberger, Department of Polytechnics, University of Rijeka, Croatia

\section{Mini Review}

Karst denominates a terrain with specific hydrogeological and geomorphological features which emanate in soluble rocks. It represents a resource of global-level significance owing to exceptional geodiversity and biodiversity abundance and the water it holds. Karst landscape is an active laboratory of quite simple but endless chemical processes. It was a huge area in a warm tropical Thetys ocean where minute shells of marine organisms accumulated for millions of years, while pressure of seawater column and own weight pressed them into compact rock. Together with Gondwana they travelled from the Equator northwards, to their present location and thus participated in forming of present architecture of continents. In the area of present-day Dinaric karst, they collide with other big continental plates and deform. Focusing on the Dinaric system (Dinarides), it represents a geologically heterogeneous, south European orogenic belt of the Alpine mountain chain and is considered as a classic karst region worldwide. The main orientation of the Dinaric system is NW-SE, parallel to the Adriatic Sea.

It is a long mountainous structure with numerous intermountain depressions including large karst poljes and valleys created by perennial or sinking streams. Some local terms were accepted, and are still used, in international karst terminology (e.g. ponor, doline, uvala, and polje, kamenitze, ponornica, bogaz, hum). Dinaric karst or carso or kras or krš is a geoecological complex which extends from Udine in Italy to Skadar lake and encompasses half of the Adriatic subsea. It includes lesser part of Slovenia, half of Croatia, about one third of Bosnia and Herzegovina, and more than $60 \%$ of Montenegro. Since the Oligocene, the Dinaric region has been continuously exposed to weathering, providing favourable conditions for intensified groundwater circulation and the development of karst features. The coast of the Adriatic owes its aspect and characteristics to karst processes in carbonate rocks - the length of as much as $5835 \mathrm{~km}$ (about $74 \%$ ) to numerous islands, peninsulas and bays and it is one of the most indented worldwide. Dinaric karst is one of the most precious karst phenomena in global terms, and at the same time the greatest continuous karst area in Europe.

Globally, Adriatic archipelago constitutes the most numerous karstic groups of islands. The presence of chemical corrosion is on the islands reinforced by salt sprays, giving rise to sharp and extreme insular relief shapes. Karst usually occupies much larger space than bare rocks that distinctly mark the landscape. It may be covered by pastures or forests, but porous features of its carbonate rocks can easily be recognized by caves, sinkholes or scarce river network. The characteristic of Dinaric karst is exceptional thickness of the rocks which naturally reach 8 $\mathrm{km}$, and somewhere, due to tectonics even twice that value. Environmental change in karst areas are important because karst environments are extremely fragile, comparable with desert margins. Once damaged, their recovery can be slow and difficult. Variation between bottom and top level of underground waters in karst - ecotone - in Dinaric karst may fluctuate to 300 metres and constitute the most valuable feature of underground habitats and are generators of species - endemic underground fauna and underground habitats made of infinite network of minute cracks in carbonate rocks.

Denuding of karst was historically the result of existential pressures of inhabitants whose numbers were booming - they ravaged vegetation cover in concentric rings around towns and villages. Karst presently does not fare well under the pressures of construction of mega-infrastructure, storage reservoirs, and tourist facilities building mania along the coast, etc. It is also a cheap raw material whose value is manifested through modest concession fee amounts. The Dinaric area contains large portion of Croatian crushed stone and dimension stone reserves. Approximately $1 / 3$ of these quarries are located within the Natura 2000 proposed Sites of Community Importance (SCI). Bulk of the problems of karst does not arise from technical neglect of its 
specific features in the institutions that manage environment, but from perception in which nature is reduced to its commercial functions. Adriatic coast, islands and reefs render their effect only during few summer months, and after that they seem to have no significance.

Coastal areas in Croatia are subject to interventions by property developers in tourism and leisure sector, whereby intense construction activity removes natural land vegetation cover. Such artificial areas, which are for some reason sometimes even proclaimed as being of strategic national interest, can in fact be found elsewhere worldwide and then serve mainly as reception capacities at times of seasonal excessive demand and exodus to the sea. The construction of such accommodation facilities in pristine places implies also the provision of water supply, wastewater treatment and waste management facilities, road networks, which all change local cover, consumes precious resources and discharges emissions to the air, land, water and the sea, thus impairing entire ecosystems in the area. Corine ${ }^{1}$ Land Cover (hereinafter CLC) nomenclature which Croatia must comply with as member of the European Union, does not identify karst. It considers the use and cover regardless of unique soil type. Karst agricultural and forest land has its use permanently changed. The main drivers of land take were building of settlements and roads and the expansion of industrial and commercial zones.

CLC data used for national statistics purposes does not necessary reveal local problems or may even fail to show the trends, which could all be misleading for local vulnerability analysis at the level of the municipality, the city, the county, watershed, forests, wetlands, or other ecosystems. At the European level, one of the main provisions of EU nature legislation is European ecological network Natura 2000 that aims to conserve selected threatened habitats and species of the EU importance. The EU Natura 2000 network represents a "cumulative action" of the two European directives: Birds Directive (2009/147/EC) and Habitats Directive (92/43/EEC). Each member state needs to examine distribution and ecological characteristics of species and habitats defined by the directives and, subsequently, to select appropriate Special Protection Areas (SPA) in accordance with the Birds Directive for bird species and Sites of Community Importance (SCI) in accordance with the Habitats Directive for other species and habitat types. These areas make up the Natura 2000 network and countries must ensure setting adequate management conservation objectives and conservation measures for habitats and species for which the sites were designated.

Habitats Directive tries to reconcile nature conservation and numerous human activities that take place in and around the Natura 2000 through the mechanism of so-called appropriate assessment (AA) of plans and projects likely to adversely affect the Natura 2000 sites. A plan or project cannot be approved unless it has been established by "appropriate assessment" that it is not likely to have significant negative consequences for the habitats and species for which the given Natura 2000 site was designated (no adverse impact on site ecological integrity). The Appropriate Assessment (AA) as defined by the directive, must give clear and legally binding answer if significant negative impact on Natura 2000 site exists; if doubts remain, it should rely on precautionary principle in favour of nature. AA requires assessment of cumulative, direct and indirect impacts of existing and planned projects and establishes a case by case approach, which excludes formation of list of specific types of projects or activities which are to be subjected to assessment. In this way it can fill in some gaps in the scope of EIA (Environmental Impact Assessment) and SEA (Strategic Impact assessment) procedures relating to smaller developments.

AA emphasis on cumulative and indirect impacts is particularly relevant in karst areas with complex underground connections where project implemented dozens of kilometres from the site may have impact on the site. Furthermore, EU Member States are encouraged to develop their own national integrated maritime policy. Very significant for an integrated approach in the management of European seas is the Marine Strategy Framework Directive 2008/56/EC (MSFD). With this directive, for the first time a comprehensive approach (in the sense that it covers the entire spectrum of marine pollution) on the protection of the marine environment in Europe was established. The Directive enshrines in a legislative framework the ecosystem approach to the management of human activities having an impact on the marine environment, integrating the concepts of environmental protection and sustainable use. The establishment of marine protected areas, under Habitats and Birds directives and under international or regional agreements to which the European Community or Member States concerned are Parties, is an important contribution to the achievement of good environmental status under MSFD Directive.

Until now $6 \%$ of European seas are designated as MPAs. Under the UN Convention on Biological Diversity, Aichi Biodiversity Target 11 the EU has committed to ensure the conservation of $10 \%$ of its coastal and marine areas by 2020 , that also being reflected in Sustainable Development Goal 14. Marine spatial planning (MSP) is considered key instrument for managing the conflicts resulting from the increasing utilization and industrialization of the world's seas and oceans since its essential elements are the ecosystem-approach, the strategic environmental assessment, and participation and consultation. Thus, under the MSP Directive 2014/89/EU the ecosystem-approach is meant to restrain the economic and social development of marine space by setting boundaries marked by the MSFD. Information on the status of the particular habitat types in Croatia are modest, although the

\footnotetext{
${ }^{1}$ Coordination of information on the environment
} 
data collected indicates the problems concerning stability of marine coastal habitats characterized by the least share of highly represented species, an indicator of how much "typical“ is habitat type in a particular area, or how many typical species are present thereon. Insignificant representation means that degraded forms of habitats are present. Coastal ecosystems are indeed subject to exceptional pressure from tourism-related activities.

However, there is an insufficient level of awareness of the specific features and susceptibility of karst despite the features which make Croatian coastal and marine areas unique and a significant geo-destination. Karst is not just tourist attraction and expenditure in terms of monitoring, but the heritage and longterm economic resource. Availability of data and comprehensible indicators would ensure sound public participation and consultation in deciding on land use. It is necessary to devise the methods of developing sufficiently responsible relationship of the public towards karst, and of decision makers, with the aim of achieving proper valuation and preservation of that national resources of ours. Appropriate protection of Dinaric karst should apply to the coast and the islands and their protection from overdevelopment, overexploitation, and destruction of natural capital they constitute. EIA procedures, when implemented in an appropriate manner, contribute to high level of protection of the environment and public health. As the issues such as sustainable development, the protection of biological diversity, climate changes as well as the risks from accidents and disasters are becoming all the more important in shaping the policies, they also represent important elements in environmental impact assessment procedures on the basis of which decisions are taken on acceptability of a particular project for the environment.

In order to achieve the highest standard of environmental protection, or realization of precautionary principle, the application of best available techniques and globally recognized systems of plants maintenance, more effective involvement of experts and scientists in the procedure of examining the projects based on environmental reports is imperative. To conclude, the EU Marine Strategy Framework Directive is an attempt to integrate various sectoral policies in reaching the balance between protection of marine ecosystems and development that needs to be sustainable. The Republic of Croatia which fulfils all the prerequisites to have prudent national marine policy a dominant one, is in fact close to default about compliance with its national and EU marine obligations. The procedure of national marine policy adoption should be made clearer and more transparent to general public, which is at the same time the public concerned, and to expert community. Any strategic vision can only be built on knowledge, education and awareness of wider public. Due to the uniqueness of the karst landscape, high fragmentation of land ownership, complex cultivation patterns, variable soil conditions, and rapid overgrowing, land cover classification should be performed for smaller landscape units. Karst region demands detailed research and accurate observation enabling historical comparisons.
Your next submission with Juniper Publishers will reach you the below assets

- Quality Editorial service

- Swift Peer Review

- Reprints availability

- E-prints Service

- Manuscript Podcast for convenient understanding

- Global attainment for your research

- Manuscript accessibility in different formats ( Pdf, E-pub, Full Text, Audio)

- Unceasing customer service

Track the below URL for one-step submission https://juniperpublishers.com/online-submission.php 